\title{
GRAVID INFUSION WATER COMPARISON FOR COLLECTION OF THE WEST NILE VIRUS VECTOR CULEX QUINQUEFASCIATUS SAY
}

\author{
NICHOLAS ACEVEDO, CAROLINE EFSTATHION, DENA AUTRY, \\ VINDHYA S. ARYAPREMA, RUI-DE XUE, AND WHITNEY QUALLS \\ Anastasia Mosquito Control District, 120 EOC Drive, St. Augustine, FL 32092
}

\author{
Guest Editor: Yongxing Jiang
}

\begin{abstract}
Gravid traps are an important tool in mosquito surveillance for the collection of gravid female mosquitoes that can be screened for arboviruses. The type of infusion water used is vital in targeting certain mosquito species, especially the West Nile vector, Culex quinquefasciatus Say. The gold standard of infusions is a whey protein mixture but is expensive and time consuming to make. The current study compared a cattail infusion to whey protein to determine if it is as effective at collecting Cx. quinquefasciatus as the current standard. If as attractive, the cattail infusion could be a more economical and less time-consuming option for use in WNV surveillance. Three sites were used to evaluate the efficacy of cattail infusion water with whey protein mixture. Each site had a trap with $100 \%$ whey protein, one with $100 \%$ cattail infusion and one with 50\% cattail water infusion. All 9 traps were operated for 24 hours for seven trap nights. Collected mosquitoes were identified, speciated, and physiological stage was assessed. There was no statistically significant difference in the total number of mosquitoes, gravid female, and total number of females amongst the three types of infusions, at any of the sites for the collection of $C x$. quinquefasciatus. These results demonstrate that a cattail infusion can be used as a more economical and less labor-intensive alternative to whey protein for the collection of $C x$. quinquefasciatus.
\end{abstract}

Key Words: Culex quinquefasciatus, West Nile virus, gravid traps, surveillance

\section{INTRODUCTION}

Arbovirus surveillance is an important component of an integrated mosquito management plan. West Nile virus (WNV) is one of the most important arboviruses due to its distribution and incidence in the United States (Petersen et al. 2013). Therefore, it has become routine for programs to screen for the virus using molecular testing of mosquito pools. The major vectors of $\mathrm{WNV}$, Culex quinquefasciatus, $C x$. pipiens $\mathrm{L}$ and $C x$. nigripalpus Theobald (Lustig et al, 2018), can be surveilled using collection methods that target the egg laying behavior of these species. Mosquito control districts programs have relied on the Reiter-Cummings gravid traps for collection of gravid mosquitoes for WNV surveillance. Gravid traps function by attracting gravid female mosquitoes with an attractive infusion water. When a mosquito lands to oviposit, she gets sucked through an opening in the trap by a fan and is retained in a capture box where she can later be identified and tested for viruses.

The most important part of the gravid trap is the infusion water used to attract the ovi-positioning mosquitoes. There is contention on best practices due to resource availability and local vector composition. Previous comparisons have been made, with varying success but ultimately no clear definition of a best practice (Allan et al. 2005). Culex mosquitoes prefer water with high organic material, so an infusion using whey protein has been developed as the gold standard in infusion water (Burkett-Cadena and Mullen 2008). To be able to produce this standard for infusion water, mosquito controls have tested and revisited the idea of what the "ideal" infusion water recipe may be. Time is a factor that can easily be overlooked when assessing the feasibility of preparing an infusion water. Some standards of making infusion water that targets WNV vectors requires investing in supplies such as 
whey protein, brewer's yeast, hay, and many more products. These ingredients have both an economical and time associated-cost to prepare the infusion. For a fiscally and/or time constrained mosquito control program these costs become a disadvantage for using the whey protein infusion. This study was to investigate if the natural flora located within a wide geographic region may provide a cheaper and less time-consuming way to make an infusion water for $\mathrm{WNV}$ surveillance.

Cattails (Typha species) are among the most common aquatic plant and have a wide geographic distribution (Bansal et al. 2019). Due to this fact, cattails are widely distributed and easily accessible. The project objective was to test an infusion water made with cattails and determine if this infusion water is as attractive or more than the infusion water in targeting gravid $\mathrm{WNV}$ vector mosquitoes, including our primary vector $C x$. quinquefasciatus.

\section{MATERIALS AND METHODS}

The sites selected for this study were chosen based on the historical abundance of $C x$. quinquefasciatus. Three locations were selected: Valencia (29 $53^{\circ} 35.7^{\prime \prime} \mathrm{N} 81^{\circ} 18^{\prime} 59.148$ " W), Ribera" (29 $9^{\circ} 52^{\prime} 36.444^{\prime \prime} \mathrm{N} 81^{\circ} 18^{\prime}$ 38.232" W) and Cartwheel Bay Avenue (30 3' 36.468" N $\left.81^{\circ} 32^{\prime} 4.452 " \mathrm{~W}\right)$. Valencia is an urban tourist area located in downtown St. Augustine, FL. The traps at Valencia were placed near flooded sewer drains and had daily foot traffic from university students in the area. These sewer drains were confirmed to be the emergence site of $C x$. quinquefasciatus. Riberia is in an area containing a water treatment facility and a number of horse stables in St. Augustine, FL. The emergence site of Cx. quinquefasciatus at Riberia was not confirmed but suspected to be around the water treatment facility. The area where the traps were placed at Cartwheel Bay (pine forest) would occasionally flood the location for the emergence site was unidentified.

This experiment took place from June to July, 2019 and consisted of seven trap nights. The whey protein infusion water was pre- pared following Burkett-Cadena and Mullen (2008) protocol. The infusion water being tested was a cattail infusion that consisted of $4 \mathrm{lbs}$ of fresh cattails (including the roots, leaves, and seed pods) in $40 \mathrm{~L}$ of water from the retention pond located on the Anastasia Mosquito Control District (AMCD) facility, and was left to ferment in a 32 gallon plastic garbage can $(2.7 \mathrm{~kg})$. Once the whey and cattail infusion waters were prepared, the solutions would ferment for 5 days prior to deployment in the field. The $50 \%$ cattail infusion water was made by taking $9 \mathrm{~L}$ and mixing with $9 \mathrm{~L}$ of DI water. A new infusion batch, both whey and cattail would be made every week.

Each evaluation site had three ReitersCummings gravid traps (BioQuip, Rancho Dominguez, CA) modified for a 6 -volt battery positioned $9 \mathrm{~m}$ apart. At each site the three infusions were evaluated using a Latin shift design and rotated weekly. The traps were set and collected in the field during the early morning. Upon retrieval, the capture boxes in each trap would be placed in a cooler to help preserve the state of each specimen for later identification. The specimens were frozen and then identified to species and physiological state (gravid, nonbloodfed, bloodfed, male) when possible, via microscopy.

The data was analyzed using IBM ${ }^{\circledR}$ SPSS ${ }^{\circledR}$ Statistics Version 20 software package. Once tested, the data sets by the Shapiro-Wilk normality test, all the comparisons were carried out by non-parametric (Kruskal-Wallis or Mann-Whitney) tests where appropriate.

\section{RESULTS \& DISCUSSION}

A total of 16 species in five genera were captured (Table 1). The highest percentage of mosquitoes collected by each infusion at each site was $C x$. quinquefasciatus (Figure 1). There were no significant differences in any of the observed parameters among the three sites (Table 2). All data were then pooled to compare the efficacy of the three infusion waters in sampling mosquitoes. None of the parameters showed significant differences among the three infusions indicating that 


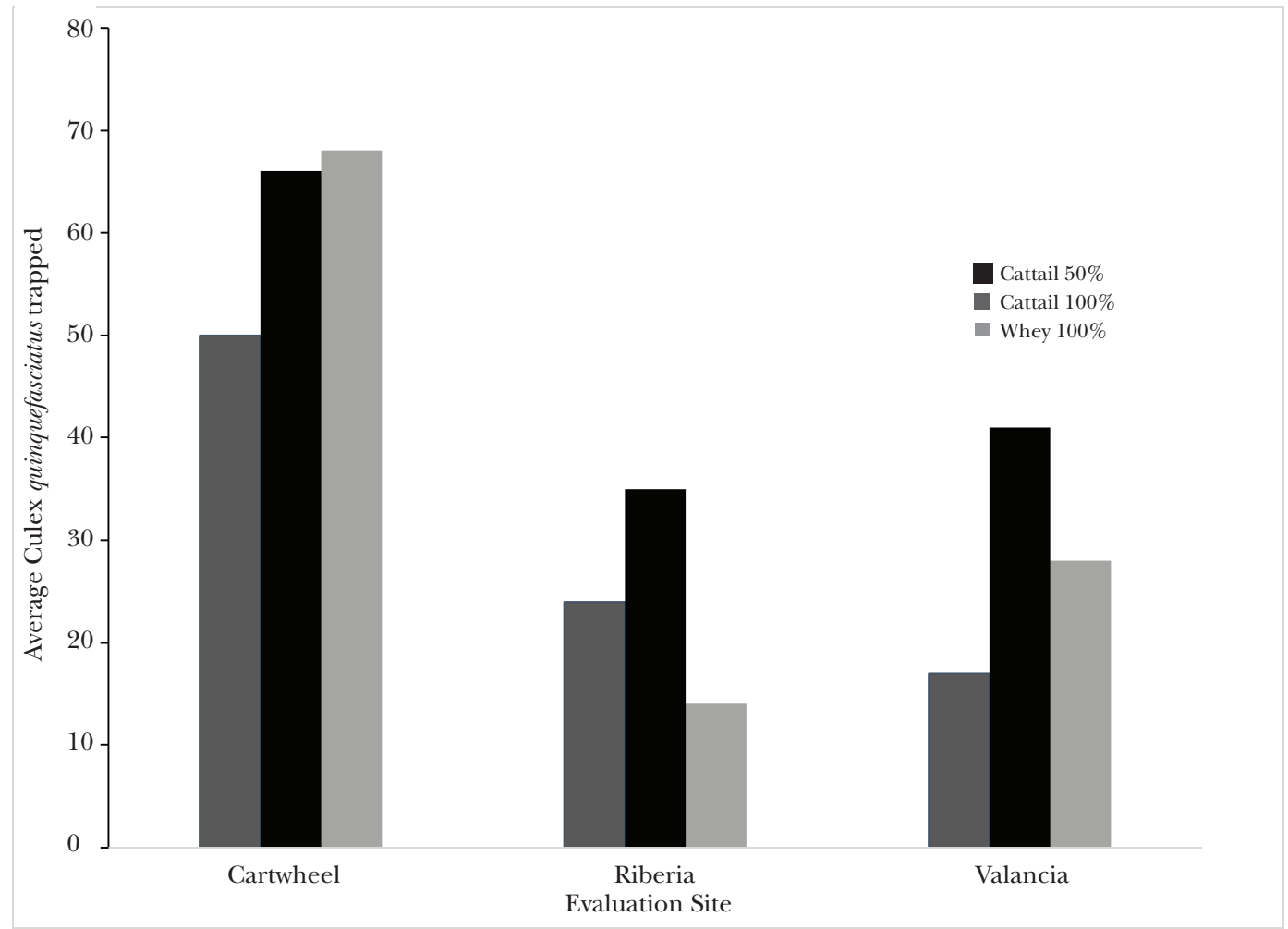

Figure 1. Average number of Cx. quinquefasciatus (male and females combined) trapped by infusion type throughout the evaluation period.

both the cattail infusions are as effective as whey protein infusion in sampling mosqui-

Table 1. Total number of mosquitoes and species collected during testing period.

\begin{tabular}{lrrr}
\hline \hline & \multicolumn{3}{c}{ Study Site } \\
\cline { 2 - 4 } Mosquito species & $\begin{array}{c}\text { Cartwhe } \\
\text { Bay }\end{array}$ & Ribera & Valencia \\
\hline Aedes aegypti & 0 & 12 & 60 \\
Ae. albopictus & 32 & 20 & 4 \\
Ae. infirmatus & 2 & 2 & 0 \\
Ae. taeniorhynchus & 0 & 2 & 0 \\
Anopheles crucians & 6 & 1 & 2 \\
An. quadrimaculatus & 4 & 0 & 0 \\
Culiseta melanura & 2 & 4 & 0 \\
Culex coronator & 0 & 7 & 0 \\
Cx. erraticus & 16 & 0 & 3 \\
Cx. nigripalpus & 22 & 28 & 8 \\
Cx. peccator & 4 & 0 & 2 \\
Cx. quinquefasciatus & 1252 & 519 & 561 \\
Cx. salinarus & 1 & 0 & 0 \\
Cx. territans & 25 & 0 & 0 \\
Uranotaenia lowii & 1 & 0 & 0 \\
Ur. sapphirina & 1 & 7 & 2 \\
Totals & 1368 & 602 & 642 \\
\hline
\end{tabular}

toes. Considering the physiological conditions of female $C x$. quinquefasciatus, the number of blood-fed females collected showed a significant difference among the three sites $\left(\chi^{2}=14.21, P=0.001\right)$ with the Cartwheel site collecting higher numbers of bloodfed mosquitoes than both Riberia $(\mathrm{U}=95.0, P=$ $0.002)$ and Valencia $(\mathrm{U}=77.0, P=0.001)$. It was not influenced by the type of the infusion ( $P>0.05$ for all) but by the trap position of Cartwheel $\left(\chi^{2}=10.94, P=0.004\right)$ and Valencia $\left(\chi^{2}=9.81, P=0.007\right)$. Positional influence on gravid females was significant only at Valencia $\left(\chi^{2}=6.843, P=0.033\right)$ while it has a significant influence on non-gravid mosquitoes at both Cartwheel $\left(\chi^{2}=8.931, P\right.$ $=0.011)$ and Valencia $\left(\chi^{2}=8.191, P=0.017\right)$.

In this study we demonstrated that cattail infusion water used in gravid traps was as attractive to $C x$. quinquefasciatus mosquitoes as the standard whey protein infusion water. The results show that both cattail infusions (100\% cattail and $50 \%$ cattail $/ 50 \%$ water) could be used as there is no difference in at- 
traction to the mosquitoes sampled in this study. The significant differences in mosquito physiological stage that was collected was due to trap position. This is in part explained by the close proximity of the gravid traps at the Cartwheel site near the AMCD sentinel chicken coup. The chickens serve as an attractant and may have increased the number of mosquitoes visiting the site, bloodfeeding, and then looking to oviposit. Thus, resulting in the increase in the number of blood-fed mosquitoes collected compared to the other two locations.

Our findings support previous work comparing whey protein infusion to cattail infusions (Allan et al. 2005, Dixon et al. 2019). Allan et al. (2005) compared the whey protein infusion to a cattail (Typha species) infusion that found both infusions to attract similar numbers of gravid Cx. quinquefasciatus. Additionally, when evaluating the gravid trap for collection of eastern equine encephalitis vectors, a whey and cattail infusion was used. This study found no significant difference in the number and abundance of species collected (Dixon et al. 2005). For resource limited or developing mosquito controls, the cattail infusion can provide great benefit in maintaining and developing an arbovirus surveillance program. The cattail is readily available during peak mosquito season and can be harvested with little to no cost.

The cattail infusion water is a low cost, easy to make alternative to the whey protein infusion water and could be a viable option for resource limited mosquito control programs. Further investigations should be carried out using the cattail infusion over the course of the mosquito season to optimize the role of this infusion in arbovirus surveillance.

\section{REFERENCES CITED}

Allan SA, Bernier UR, Kline DL. 2005. Evaluation of oviposition substances and organic infusions on collection of Culex in Florida. J Am Mosq Control Assoc 21:268-273.

Bansal S, Lishawa SC, Newman S, Tangen BA, Wilcox D, Albert D, Anteau MF, Chimney MJ, Cressey RL, DeKeyser E, Elgersma KJ, Finkelstein SA, Freeland J, Grosshans R, Klug PE, Larkin DJ, Lawrence BA, Linz G, Marburger J, Noe G, Otto C, Reo N, Richard 
J, Richardson C, Rodgers L, Schrank AJ, Syedarsky D, Travis S, Tuchman N, Windham-Myers L. 2019. Typha (Cattail) invasion in North American wetlands: biology, regional problem, impacts, ecosystem services, and management. Wetlands 39:645-694. Burkett-Cadena ND, Mullen GR. 2008. Comparison of infusion of commercially available garden products for collection of container-breeding mosquitoes. $J$ Am Mosq Control Assoc 24:236-243.
Dixon D, Auty D, Xue RD 2019. Evaluation of multiple trap types for the capture of vector mosquitoes of eastern equine encephalitis virus in St. Johns county, Florida. JF Mosq Control Assoc. 66:11-19.

Lusting Y, Sofer D, Bucris ED, Mendelson F. 2018. Surveillance and diagnosis of west nile virus in the face of Flavivirus cross-reactivity. Front Microbiol 9:2421.

Petersen LR, Brault AC, Nasci RS. 2013. West nile virus review of the literature. JAm Med Assoc 310:308-315. 